International Journal of Engineering \& Technology, $7(3.30)(2018) 262-264$
International Journal of Engineering \& Technology
Website: $w$ ww.sciencepubco.com/index.php/IJET
Research paper

\title{
Competence of Architects in the Context of Jakarta Socio-Cultural-Ecology Architecture
}

\author{
Sigit Wijaksono $^{1}$, Sasmoko $^{2,3 *}$, Yasinta Indrianti $^{2}$, Samuel Anindyo Widhoyoko ${ }^{3}$ \\ ${ }^{I}$ Department of Architecture, Faculty of Engineering, Bina Nusantara University, Indonesia \\ ${ }^{2}$ Research Interest Group in Education Technology, Bina Nusantara University, Indonesia \\ ${ }^{3}$ Faculty of Humanities, Bina Nusantara University, Indonesia \\ ${ }^{4}$ Forensic Accounting, Podomoro University, Indonesia \\ *Corresponding author E-mail: sasmoko@binus.edu
}

\begin{abstract}
One city is determined by the characteristics of the urban developing building. The characteristics of the building are determined by the architectural capacity that is influenced by the culture, social and the surrounding environment. In Indonesian cities especially Jakarta, competency standards are needed as a professional detection tool that keeps the legacy of a city of art and building. The problem to be found in this research is how the building of competence that marks a competent architecture for Jakarta. The research method used is exploratory research as one of the stages in Neuroresearch research model. The results of the study found that there are 13 competencies that are able to describe the urban legacy within the architect in the context of the Jakarta Socio Cultural Ecology Architecture.
\end{abstract}

Keywords: Competence Architects, Jakarta Socio-Cultural-Ecology Architecture, Neuroresearch.

\section{Introduction}

Characteristics of buildings in an urban are very important. A study even illustrates the link between building characteristics and the lifestyles of people living in the city [1]. In China, urbanization and modernization have been able to change the characteristics of existing buildings even though they vary depending on the socioeconomic status of local communities [2].

Jakarta is the capital of a densely populated Indonesian state with an area of approximately $661.52 \mathrm{sq} \mathrm{km}$. The city of Jakarta is located in the lowlands of the north coast of West Java Province with a relatively flat area. The city of Jakarta regionally has five main landscapes, namely volcanic landscape, marine-origin landscape, landscape coastal landau, swamp and mangrove swamp landform and former river channel [3]. Over the past few years, the development of Jakarta has grown exponentially and has impacted on several issues such as environmental problems and land subsidence [4]. The rapid growth of the city of Jakarta in the field of industry, trade, transportation, real estate and various other sectors increase urbanization so that the population in the city of Jakarta also increased dramatically. The resulting impact is the building that is increasingly reducing the green area in Jakarta [5]. Growth and development in the city of Jakarta have many aspects that need to be a common concern. Some of the impacts caused by such rapid growth are the decline of land resulting in the cracking of existing buildings and infrastructure and flooding at various points in Jakarta [6]. From another point of view, the development of a city also needs to pay attention to the social and economic factors of society so that it opens up opportunities so that each social group can interact with each other well [7].

To obtain the characteristics of buildings that can capture the rapid growth of society but still pay attention to various related factors, the architectural competence becomes one of the important things that must also be considered especially in the concept of Jakarta Socio-Cultural-Ecology. The capacity of architects in collaborating with building works is a decisive factor because it is influenced by different perspectives in terms of geography, social, and local culture. The problem to be found in this research is how to build competence that marks the architecture that is competent for the concept of Jakarta Socio-Cultural Ecology.

\section{Literature Review}

\subsection{Architect}

Architecture is a manifestation of the application of science, technology and art that is fully able to change the space and the built environment as part of human culture and civilization that fulfills the rules of function, construction and aesthetics and includes the factors of safety, security, health, comfort and convenience. While the architect is a person who performs architectural practices, namely activities organized to produce architectural works that include planning, design, supervision and / or assessment of buildings and their environment and associated with the region and the city [8].

\subsection{Jakarta Socio-Cultural-Ecology}

Jakarta Socio-Cultural-Ecology is a concept of settlement that has a paradigm able to highlight the original culture, built by looking at the social and economic activities of the community and maintaining the inheritance value of every existing building [9]. 


\section{Research Method}

This research uses Neuroresearch research method, focusing on exploratory research effort through journal exploration and various studies that can support the research concept $[10,11,12]$ Research exploratory research method is an early stage that is usually done in Neuroresearch, so this research can be called as preliminary research.

\section{Result}

Ikatan Arsitek Indonesia has given thirteen points of competence which become the basic guidance of Architectural Skill Certificate (SKA) by Architects Architects Council Architects (Indonesia, n.d.).

Thirteen architectural competencies are as follows:

1. Have the ability in architectural design that meets the aesthetic and technical requirements and aims to preserve the environment;

2. Have adequate architectural knowledge about history and architecture theory including art, technology and human science;

3. Having knowledge of art and its influence on the quality of architectural design

4. Capable of planning and designing the city and having the necessary skills in the planning process;

5. Able to build harmonious relationships between people, buildings and the environment and understand the importance of linking the space formed between people, buildings and the environment;

6. Have knowledge in terms of environmental carrying capacity;

7. Able to portray architecture in the community by taking into account social factors;

8. Have the ability to prepare design work by understanding the method of tracking and preparing the design program;

9. Able to build the meaning of interdisciplinary issues related to the structure, construction and engineering related to the design of buildings;

10. 10. Have good knowledge about physical and physics of building, technology and building function of Building and equip with internal condition which gives comfort and protection to local climate;

11. Have the ability to synergize between budget constraints and building regulations;

12. Having knowledge of industry, organization, rules and procedures relating to the process of translating the design concept;

13. Have knowledge about project management both funding and development cost control.

Fulfillment of the thirteen competences of the above architects can be one of the benchmarks of the successful development of the Jakarta Socio-Cultural-Ecology. Where this competence can support the realization of three dimensions that exist in Jakarta SocioCultura-Ecology.

The first dimension is related to the ability of architects in promoting indigenous culture. In particular, this dimension will be realized optimally with the existence of the second architect's competence when they have adequate architectural knowledge about the history and theory of architecture including art, technology and human science.

The second dimension of development that is able to highlight the relevance of social and economic activities of the people of Jakarta will be supported specifically through the competence of the fourth architect in planning and designing the city and having the skills needed in the planning process; the fifth competence of building a harmonious relationship between human, building and environment and understanding the importance of linking the space formed between human, building and its environment; the sixth competence is knowledge in terms of environmental carrying capacity; and the seventh competence of playing the architecture in the community with attention to social factors.

While the third dimension is to maintain the value of the inheritance of existing buildings can be supported by the first competence is the ability in architectural design that meets the aesthetic and technical requirements and aims to preserve the environment; second competence is adequate architectural knowledge about history and architecture theory including art, technology and human science; and third competence is the knowledge of art and its influence on the quality of architectural design.

\section{Discussion}

Jakarta Socio-Cultural-Ecology is a modern architecture that does not leave the original culture because it prioritizes the value of inheritance as one of the characteristics of the building to be developed. Called modern architecture because it is made in the modern period and still put forward the value of modernity because it must collaborate the socio-economic conditions of local communities [13]. This is important because the architectural style of the house into consideration for consumers both in appearance and functional layout [14]. Thus, to produce such a concept requires the special competence of architects that have been contained in thirteen competencies developed by the Association of Indonesian Architects. Competence fulfillment will be one of the benchmarks of architect's success in building Jakarta SocioCultural-Ecology.

\section{References}

[1] Liu W, Huang C, Hu Y, Zou Z, Shen L \& Sundell J (2015), Associations of Building Characteristics and Lifestyle Behaviors with Home Dampness-related Exposures in Shanghai Dwellings. Building and Environment 88, 106-115.

[2] Liu W, Huang C, Hu Y, Zou Z, Zhao Z \& Sundell J (2014), Association of building characteristics, residential heating and ventilation with asthmatic symptoms of preschool children in Shanghai: A cross-sectional study. Indoor and Built Environment 23(2), 270-283. https://doi.org/10.1177/1420326X13516970

[3] Abidin HZ, Andreas H \& Gumilar I (2010), Land subsidence characteristics of the Jakarta basin ( Indonesia ) and its relation with groundwater extraction and sea level rise Land Subsidence Characteristics of the Jakarta Basin ( Indonesia ) and its Relation with Groundwater Extraction and Sea Leve. Groundwater Response to Changing Climate, 113-130. https://doi.org/10.1201/b10530-11

[4] Abidin HZ, Andreas H, Gumilar I, Fukuda Y, Pohan YE \& Deguchi $\mathrm{T}$ (2011), Land subsidence of Jakarta (Indonesia) and its relation with urban development. Natural Hazards 59(3), 1753-1771. https://doi.org/10.1007/s11069-011-9866-9

[5] Abidin HZ, Andreas H, Gumilar I \& Gamal M (2009), Land Subsidence and Urban Development in Jakarta (Indonesia ). In 7th FIG regional conference, spatial data serving people: land governance and the environment, Hanoi, Vietnam, 19-22.

[6] Abidin HZ, Andreas H, Gumilar I \& Wibowo IRR (2015), On correlation between urban development, land subsidence and flooding phenomena in Jakarta. IAHS-AISH Proceedings and Reports, 370, 15-20. https://doi.org/10.5194/piahs-370-15-2015

[7] Leaf M (1996), Building the road for the BMW: Culture, vision, and the extended metropolitan region of Jakarta. Environment and Planning A, 28(9), 1617-1635. https://doi.org/10.1068/a281617

[8] Republik Indonesia UUN 6 (2017), Arsitek.

[9] Wijaksono S, Sasmoko, Indrianti Y \& Widhoyoko SA (2017), Jakarta socio-cultural ecology: a sustainable architecture concept in urban neighbourhood To. IOP Conf. Series: Earth and Environmental $\quad$ Science, $\quad 109(1), \quad 012044$. https://doi.org/10.1088/1755-1315/

[10] Fios F, Sasmoko \& Gea AA (2016), Neuro-Research Method: A Synthesis Between Hermeneutics and Positivism. Advanced $\begin{array}{lll}\text { Science } & \text { Letters } & \text { 22(9), }\end{array}$ https://doi.org/10.1166/as1.2016.7565

[11] Sasmoko \& Anggriyani D (2016), Neuroresearch (A Model of Research Method). In A. Khan, M. N. A. Ghafar, A. R. Hamdan, \& 
R. Talib (Eds.), Research on Educational Studies (2016th ed., pp. 33-45). New Delhi: Serial Publications PVT. LTD.

[12] Sasmoko, Indrianti Y, Karsidi R, Wuisan D \& Ruliana P (2018),

Neuroresearch: Another form of mixed method. International Journal of Engineering and Technology(UAE) 7(2), 134-138. https://doi.org/10.14419/ijet.v7i2.10.10971

[13] Frampton K \& Futagawa Y (1983), Modern Architecture. Architecture. ADA Edita. https://doi.org/10.1378/chest.66.4.388

[14] Asabere PK, Hachey G \& Grubaugh S (1989), Architecture, historic zoning, and the value of homes. The Journal of Real Estate Finance and Economics 2(3), 181-195. https://doi.org/10.1007/BF0015234. 